\title{
DIFFERENTIATION OF THE FINANCIAL STANDING OF THE MUNICIPALITIES OF ŚWIĘTOKRZYSKIE VOIVODESHIP IN THE ASPECT OF THEIR FINANCIAL INDEPENDENCE ${ }^{1}$
}

\begin{abstract}
Summary
Puppose - The purpose of the article is to rate the diversity of the financial situation of municipalities in Swiętokrzyskie voivodship in relation to their financial independence.

Research method - The financial situation and independence are multidimensional. They are shaped by, among others, economic, legal and financial factors. The assessment of the financial standing and independence was based on the value of the synthetic measure determined by the TOPSIS method. The study covered the years 2009-2018. The article uses data obtained from the Regional Accounting Chamber of Kielce.

Results - The subject of the discussion presented in the article are the issues of the financial situation and independence of the municipalities (102) of Świętokrzyskie voivodship. As part of the research, a set of diagnostic variables was selected, their nature, synthetic measure, and their division into quartile groups were determined.

Originality / value - Stability and certainty of income determine the scope and level of tasks performed by the municipalities. The financial situation and independence of municipalities are not a permanent category. The financial situation of the municipalities in Świętokrzyskie voivodship was shaped by the development potential, the level of financing public services and implemented transfers, income and expenses independence and budget solvency. The best municipalities were characterized by a good situation and a high level of financial independence.
\end{abstract}

Keywords: commune, financial situation, financial independence, synthetic measure

JEL Classification: H70, H71, H72

\section{Introduction}

Municipalities as the basic units of the territorial division of the country are the core of the local government system [Prus, Wawrzyniak, 2011, pp. 77-92]. Their tasks are related to meeting the needs of the local community, and the activities are not focused on economic profit. The municipalities' incomes are their own income,

1 Article received on 17 March 2020, accepted on 20 April 2020. 
general subsidy and targeted subsidies from the state budget. Their analysis allows not only to assess the structure of the budget itself, but also indirectly provides information on the state of the local economy.

The assessment of the financial situation allows to determine the efficiency of the commune. It indicates the possibility of fulfilling its obligations and raising the quality standard of services provided to local communities [Dziekański, 2016]. Financial situation is a condition of sustainable social and economic development of the commune. There is a correlation between the financial situation of municipalities and their level of development (understood as a complex of quantitative and qualitative transformations regarding the standard of living of residents and the functioning of economic entities) [Sobczyk, 2010, pp. 125-136].

\section{Purpose and research method}

The purpose of the article is to rate the diversity of the financial situation of municipalities in Świętokrzyskie voivodship in relation to their financial independence using a synthetic measure. Empirical data was collected for 102 municipalities of Świętokrzyskie voivodeship. As the source material, data from the Regional Accounting Chamber of Kielce was used for the years 2009-2018. In the context of assessing the financial situation of municipalities, the variables in table 1 were used.

TABLE 1

List of variables describing the financial situation of municipalities

\begin{tabular}{|l|c|c|}
\hline \multicolumn{1}{|c|}{ Variable } & Unit & S/D \\
\hline Budget surplus / deficit per capita (assessment of budget solvency) & $\mathrm{pln}$ & $\mathrm{S}$ \\
\hline Interest / own income (debt service ratio) & $\%$ & $\mathrm{D}$ \\
\hline Total income / total expenses (budget efficiency) & $\%$ & $\mathrm{~S}$ \\
\hline Operating surplus / total income (in terms of budget solvency) & $\%$ & $\mathrm{~S}$ \\
\hline Own income / total income (financial independence) & $\%$ & $\mathrm{~S}$ \\
\hline Investment expenses / total expenses (in terms of investment attractiveness) & $\%$ & $\mathrm{~S}$ \\
\hline Income from local taxes and fees / total income (level of fiscal wealth) & $\%$ & $\mathrm{~S}$ \\
\hline Total subsidies / total income (ratio of financial state interference) & $\%$ & $\mathrm{D}$ \\
\hline Subsidies / total income (ratio of financial state interference) & $\%$ & $\mathrm{D}$ \\
\hline Debt / own income (solvency ratio of own income) & $\%$ & $\mathrm{D}$ \\
\hline Expenses on transport and communication / population & $\mathrm{pln}$ & $\mathrm{S}$ \\
\hline Expenses on education and upbringing / number of inhabitants & $\mathrm{pln}$ & $\mathrm{S}$ \\
\hline Expenses on housing / population & $\mathrm{pln}$ & $\mathrm{S}$ \\
\hline Expenses on municipal economy and environment protection / population & $\mathrm{pln}$ & $\mathrm{S}$ \\
\hline Health care expenses / population & $\mathrm{pln}$ & $\mathrm{S}$ \\
\hline Expenses on social policy / population & $\mathrm{pln}$ & $\mathrm{S}$ \\
\hline
\end{tabular}

$\mathrm{s}$ - stimulant; d - destimulant

Source: author's own work: [Głowicka-Wołoszyn, Wysocki, 2014; Wang et al., 2007; Stanny, Strzelczyk, 2018]. 
Examination of financial independence means the assessment of a complex trait. It is determined by economic, legal and financial factors [Wyszkowska, 2018]. To characterize the financial independence of the municipalities, the variables listed in table 2 were used.

TABLE 2

List of variables describing the financial independence of municipalities

\begin{tabular}{|l|c|c|}
\hline \multicolumn{1}{|c|}{ Variables } & Unit & $\mathbf{S} / \mathbf{D}^{\mathbf{a}}$ \\
\hline Own income / total income & $\%$ & $\mathrm{~S}$ \\
\hline Tax income and local fees / number of inhabitants & $\mathrm{pln}$ & $\mathrm{S}$ \\
\hline Tax income and local fees / current income & $\%$ & $\mathrm{~S}$ \\
\hline Transfer income / total income & $\%$ & $\mathrm{D}$ \\
\hline Self-financing rate & $\%$ & $\mathrm{~S}$ \\
\hline Investment expenses / total expenses & $\%$ & $\mathrm{~S}$ \\
\hline
\end{tabular}

s - stimulant; d - destimulant

Source: author's own work: [Głowicka-Wołoszyn, Wysocki, 2014; Wang et al., 2007; Stanny, Strzelczyk, 2018].

The study was carried out in the following stages [Dziekański, 2016, pp. 79-91]:

1. Choosing a set of diagnostic variables and determining their nature.

After selecting the variables, the nature of each variable was examined, i.e. it was determined whether the variable was a stimulant or destimulant. The variables with low variability (according to the coefficient of variation) and high correlation of variables (according to the inverted matrix method) were removed from the set of variables [Malina, 2004, pp. 96-97].

2. Replacement of destimulants with stimulants and standardization of variables.

Variable destimulants were transformed into stimulants according to the formula [Kolenda, 2003, 110-127]:

$$
x_{i j}=\frac{1}{x_{i j}}
$$

The selected variables were subjected to the procedure of zero unitarization using the following formula:

$$
z_{i j}=\frac{\mathrm{x}_{i j}-\min _{i} \mathrm{x}_{i j}}{\max _{i} \mathrm{x}_{i j}-\min _{i} x_{i j}} \text { when } \quad x_{i} \in S
$$

where: $\mathrm{S}$ - stimulant, $\mathrm{i}=1,2 \ldots \mathrm{n} ; \mathrm{j}=1,2 \ldots \mathrm{n}$, xij - means the value of the $\mathrm{j}$-t feature for the examined unit, max - the maximum value of the $j$-t feature, min - the minimum value of the $\mathrm{j}$-t feature [Młodak, 2006].

3. Designing a measure of the synthetic financial situation and determining the measures of financial independence 
A synthetic measure of the situation and financial independence was determined separately for each commune using the TOPSIS method, taking into account the distance between the unit and the template $(=1)$ and anti-template $(=0)$. Then the Euclidean distances of individual objects from the pattern and anti-pattern engine were calculated according to the following formulas:

$$
\begin{aligned}
& d_{i}^{+}=\sqrt{\frac{1}{n} \sum_{j=1}^{m}\left(z_{i j}-z_{j}^{+}\right)^{2}} \\
& d_{i}^{-}=\sqrt{\frac{1}{n} \sum_{j=1}^{m}\left(z_{i j}-z_{j}^{-}\right)^{2}}
\end{aligned}
$$

where: $\mathrm{n}-$ is the number of variables that make up the pattern or anti-pattern, $\mathrm{z}_{i j}-$ means the unified value of the $j$-t feature for the unit being tested, $z_{j}^{+}, z_{j}^{-}$- means the object of the pattern or anti-pattern [Wójcik-Leń et al., 2019; Zalewski, 2012, pp. 137-145].

The measure of financial standing and independence according to the TOPSIS method for individual objects was determined on the basis of the formula:

$$
q_{i}=\frac{d_{i}^{-}}{d_{i}^{-}+d_{i}^{+}}, \text {when } 0 \leq q_{i} \leq 1, i=1,2, \ldots, n ;
$$

with: $q i \in[0 ; 1]$; $\operatorname{maxi}\{q i\}$ - the best object; $\operatorname{mini}\{q i\}$ - the worst object $d_{i}^{-}$means the distance of the object from the anti-template (from 0$), d_{i}^{+}$means the distance of the object from the template (from 1). The higher value of the measure indicates a better situation of the individual in the studied area [Hwang, Yoon, 1981; Pietrzak, 2016, pp. 69-86; Behzadian et al., 2012].

4. Building a ranking of the municipalities surveyed according to their level of financial standing and their division into classes.

In the last stage of the analysis, in order to interpret the obtained measures, the division into quartile groups was used, where the size of the indicator in the first group means a better unit and in subsequent groups - worse units. The mutual consistency of the results obtained was also verified using the correlation coefficient and a synthetic measure scatter chart was presented [Dziekański, 2016; Zeliaś, Malina, 1997].

\section{Financial situation of municipalities}

Financial resources ensure the achievement of the entity's objectives in terms of current or development tasks. The inflow of new residents and investors to the area of a given unit translates into an increase in budget incomes. There is a correlation between socioeconomic and financial variables. The inflow of new investors locating enterprises in a given commune occurs in economically developed units Dennis, 2004, pp. 43-45; Standar, 2017, pp. 69-92]. 
The analysis conducted by Churski and his co-authors [2013] as well as Stanny and Strzelczyk [2017] or Dziekański [2016] show that finance is a factor of development. In the conducted research, the authors focused on the issue of municipal incomes and investment expenses, emphasizing their importance from the point of view of the potential financing of development-oriented tasks of local governments. The financial situation allows for a comprehensive assessment of the operation of a municipality and its development opportunities and refers to the state of its finances within a specified period of time. Its level is shaped by, among others, the ability to achieve a budget balance or increase the commune's assets. The analysis of the financial situation should include, among others, the income level, financial independence, the amount of investment expenses, the financial result achieved by the commune [Ossowska, Ziemińska, 2010, pp. 73-74].

Douglas and Gaddie [2002] refer the financial situation in terms of the possibility of timely fulfillment of financial obligations and ensuring continuity in the provision of services. As indicated by Cabaleiro-Casal et al. [2013] the financial situation should not be described in a one-dimensional space (one indicator). Income and expenses of municipalities are complex and multidimensional values with different time frames.

The financial independence of municipalities can be defined as the right to selfdetermine the budget and taking responsibility for its implementation, the ability to shape the structure of own income, freedom to decide on the type and amount of expenses, the right to use debt instruments [Rechul, 2013, pp. 229-230]. The assessment of the degree of financial independence is difficult due to various levels on which financial independence and the selection of appropriate measures can be considered [Wyszkowska, Wyszkowski, 2015, pp. 131-142]. Financial independence is influenced by many different factors, such as: legal, economic, financial, social and institutional development of the state. In addition, economic prosperity is affected by the economic situation [Galiński, 2011; Fllipiak, 2011].

Financial independence in the sphere of income is usually reduced to the powers of local self-government bodies in conducting fiscal policy in a given area [KosekWojnar, Surówka, 2002]. Own income is often treated as an indicator of the wealth of a commune and a basic source of information about its financial situation and level of independence. The scope of the municipalities' freedom to spend their income is related to the level of their own income and it determines the correct process of providing public services or the ability to perform development and ongoing tasks [Surówka, 2013; Kozera et al., 2016]. This requires not only an adequate level of income, but also the ability to make decisions in tax matters independently.

Independence in the sphere of expenses can be understood as the free spending of funds under the self-government's responsibility. Capital expenses are evidence of the desire of municipalities to increase their ownership. They contribute to improving the living conditions of the inhabitants and to the general socio-economic development [Surówka, 2013; Kosek-Wojnar, 2006]. 


\section{Diversification of the financial situation of municipalities versus their financial independence}

The Świętokrzyskie Voivodship has an industrial and agricultural character. The main industries of the Świętokrzyskie region are: metallurgical (Ostrowiec Świętokrzyski), metal (Skarżysko-Kamienna), machine (Starachowice), building materials (Kielce), ceramic, foundry (Końskie), food (Pińczów, Kielce). The region of the voivodship is attractive for tourists (i.a. Święty Krzyż, Sandomierz, Krzemionki Opatowskie). The voivodship has favorable natural conditions for the development of agriculture (kazimierski, sandomierski, opatowski poviats).

TABLE 3

Municipalities of the Świętokrzyskie Voivodship divided into groups according to a measure of the synthetic financial situation in 2009 and 2018

\begin{tabular}{|c|c|c|c|c|c|}
\hline \multirow{2}{*}{ Gr } & \multicolumn{2}{|l|}{2009} & \multicolumn{2}{|l|}{2018} & \multirow{2}{*}{$2018 / 2009$} \\
\hline & Municipality & TOPSIS & Municipality & TOPSIS & \\
\hline \multirow{4}{*}{ I } & Sitkówka-Nowiny (2) & 0.40 & Sitkówka-Nowiny (2) & 0.42 & 0.05 \\
\hline & Ożarów (3) & 0.34 & Połaniec (3) & 0.40 & 0.18 \\
\hline & Połaniec (3) & 0.34 & Kielce (1) & 0.34 & 0.13 \\
\hline & Morawica (2) & 0.33 & Busko-Zdrój (3) & 0.32 & 0.10 \\
\hline \multirow{4}{*}{ II } & Łoniów (2) & 0.26 & Bieliny (2) & 0.26 & 0.04 \\
\hline & Małogoszcz (3) & 0.26 & Bodzechów (2) & 0.26 & 0.08 \\
\hline & Michałów (2) & 0.26 & Bodzentyn (3) & 0.26 & 0.18 \\
\hline & Osiek (3) & 0.26 & Górno (2) & 0.26 & 0.08 \\
\hline \multirow{4}{*}{ III } & Bejsce (2) & 0.23 & Brody (2) & 0.24 & 0.09 \\
\hline & Chmielnik (3) & 0.23 & Działoszyce (3) & 0.24 & -0.25 \\
\hline & Gowarczów (2) & 0.23 & Imielno (2) & 0.24 & 0.09 \\
\hline & Lopuszno (2) & 0.23 & Jędrzejów (3) & 0.24 & -0.04 \\
\hline \multirow{7}{*}{ IV } & Bliżyn (2) & 0.21 & Bliżyn (2) & 0.23 & 0.10 \\
\hline & Kunów (3) & 0.21 & Ćmielów (3) & 0.23 & -0.04 \\
\hline & Mirzec (2) & 0.21 & Dwikozy (2) & 0.23 & -0.04 \\
\hline & Moskorzew (2) & 0.21 & $\begin{array}{c}\text { Kazimierza Wielka } \\
\text { (3) }\end{array}$ & 0.23 & -0.04 \\
\hline & Ruda Maleniecka (2) & 0.18 & Opatowiec (2) & 0.21 & 0 \\
\hline & & & Radków (2) & 0.21 & -0.28 \\
\hline & & & Tarłów (2) & 0.21 & 0.11 \\
\hline
\end{tabular}

in table the best units in the group; the best and weakest individual in the community; the number in parentheses next to the communes name means (1) urban communes; (2) rural communes; (3) urban and rural communes

Source: author's own work based on data from RIO o / Kielce. 
In 2018, the measure of financial situation ranged from 0.21 (Opatowiec (2), Tadków (2), Tarłów (2), the weakest units) to 0.42 (Sitkówka-Nowiny (2); the best unit), while in 2009 from 0.18 (Ruda Maleniecka (2)) to 0.40 (Sitkówka-Nowiny (2)). The range of values adopted by the measure of financial situation was slightly lower in 2018 (range 0.21) than in 2009 (range 0.22) (table 3).

In 2018, the measure of financial independence was charactrized by values from 0.11 (Oksa (2)) to 0.58 (Sitkówka-Nowiny (2)), and in 2009 from 0.08 (Słupia Konecka (2)) to 0.57 (Sitkówka-Nowiny (2)). The range of values adopted by the measure of financial independence was slightly lower in 2018 (range 0.47) than in 20009 (0.49) (table 4).

TABLE 4

\section{Municipalities of the Świętokrzyskie Voivodship divided into groups according to the measure of synthetic financial independence in 2009 and 2018}

\begin{tabular}{|c|c|c|c|c|c|}
\hline \multirow{2}{*}{ Gr } & \multicolumn{2}{|l|}{2009} & \multicolumn{2}{|l|}{2018} & \multirow{2}{*}{$2018 / 2009$} \\
\hline & Municipality & TOPSIS & Municipality & TOPSIS & \\
\hline \multirow{4}{*}{$\mathrm{I}$} & Sitkówka-Nowiny (2) & 0.57 & $\begin{array}{c}\text { Sitkówka-Nowiny } \\
\text { (2) }\end{array}$ & 0.58 & 0.02 \\
\hline & Połaniec (3) & 0.47 & Połaniec (3) & 0.54 & 0.15 \\
\hline & Ożarów (3) & 0.45 & Ożarów (3) & 0.41 & -0.09 \\
\hline & Sandomierz (1) & 0.45 & Sandomierz (1) & 0.39 & -0.13 \\
\hline \multirow{4}{*}{ II } & Kazimierza Wielka (3) & 0.26 & Chmielnik (3) & 0.24 & 0.14 \\
\hline & Łączna (2) & 0.26 & Działoszyce (3) & 0.24 & -0.33 \\
\hline & Osiek (3) & 0.26 & Lagów (2) & 0.24 & 0.26 \\
\hline & Strawczyn (2) & 0.26 & Oleśnica (2) & 0.24 & -0.23 \\
\hline \multirow{4}{*}{ III } & Dwikozy (2) & 0.20 & Czarnocin (2) & 0.20 & 0.11 \\
\hline & Michałów (2) & 0.20 & Strawczyn (2) & 0.20 & -0.23 \\
\hline & Nowa Słupia (2) & 0.20 & Zagnańsk (2) & 0.20 & 0.11 \\
\hline & Sadowie (2) & 0.20 & Bodzentyn (3) & 0.19 & 0.12 \\
\hline \multirow{5}{*}{ IV } & Fałków (2) & 0.16 & Nagłowice (2) & 0.15 & -0.06 \\
\hline & Kluczewsko (2) & 0.16 & Obrazów (2) & 0.15 & -0.38 \\
\hline & Nagłowice (2) & 0.16 & Radków (2) & 0.15 & -0.55 \\
\hline & Sobków (2) & 0.16 & Zawichost (3) & 0.15 & -0.12 \\
\hline & Słupia Konecka (2) & 0.08 & Oksa (2) & 0.11 & -0.54 \\
\hline
\end{tabular}

in table the best units in the group; the best and weakest unit in the community

Source: author's own work based on data from RIO o / Kielce. 


\section{CHART 1}

Map of spatial differentiation of the measure of the synthetic situation and financial independence of municipalities of Świętokrzyskie Voivodship in 2009 and 2018

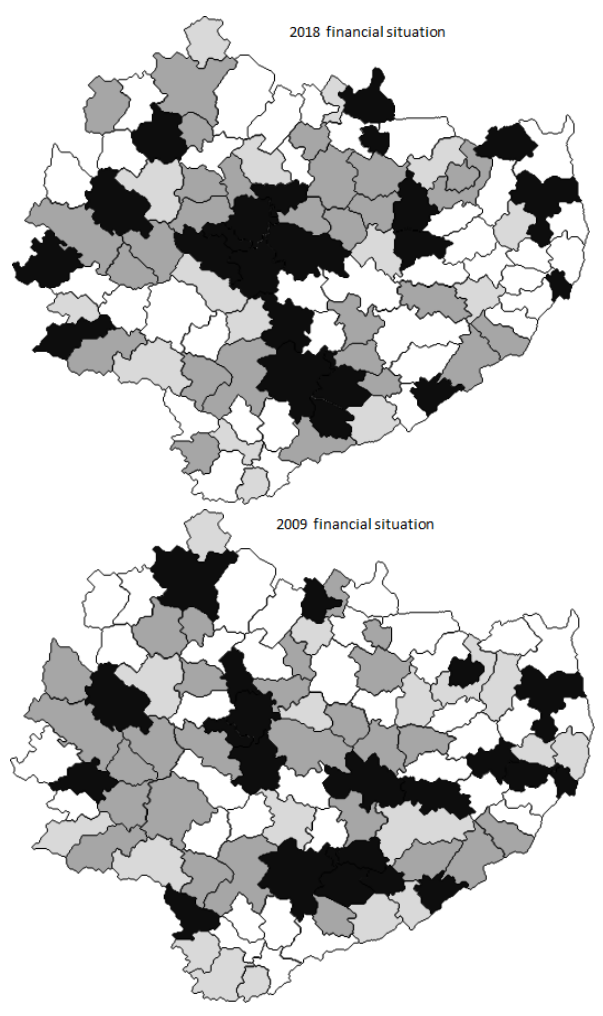

according to financial situation
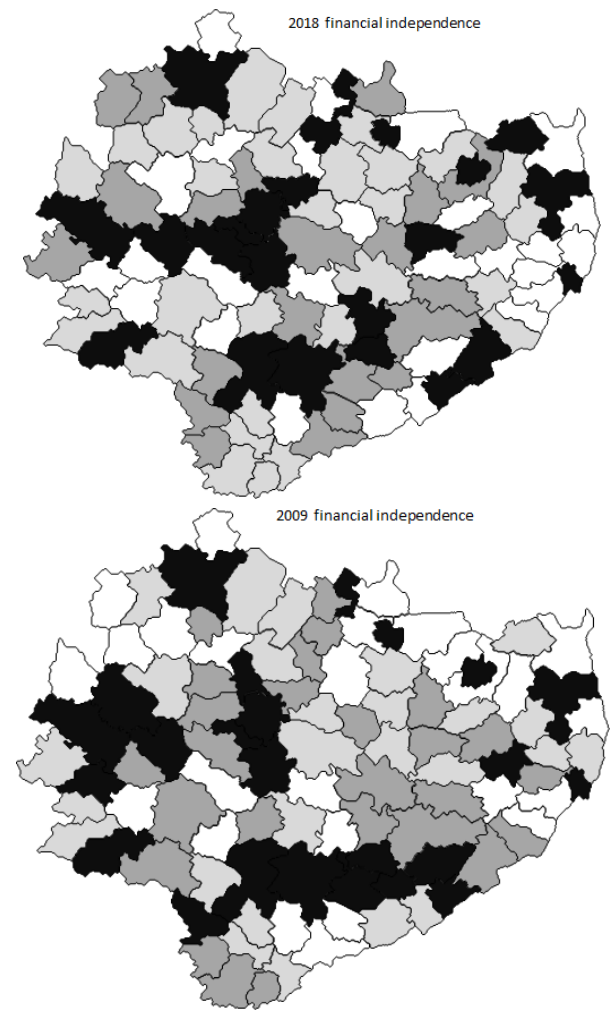

according to financial independence

\section{gr I} gr II

gr III

gr IV

Source: author's own work.

The financial situation and independence of municipalities were determined, among others, by own income, income from local fees and taxes, investment expenses, the number of employed persons as well as entities and persons conducting business activity (cf. table 6 ). The ranking of municipalities in the examined aspects showed high notes of Sitkówka-Nowiny (2), Połaniec (3), Kielce (1), Busko-Zdrój (3), Ożarów (3), Sandomierz (1), and Morawica (2). These are municipalities of group I (black in chart 1). These are the central parts of the voivodship characterized by a developed industrial function, a spa and tourist function as well as a developing labor market and a good financial situation and independence. Similar conclusions were reached by the authors of other studies, in which it was found that high financial independence is the result of local entrepreneurship [Satoła et. al., 2019, pp. 321-342]. 
The analysis of the diversity of the measure of the synthetic financial situation indicates that in 2018 compared to 2009, the degree of diversity of municipalities was smaller. This is evidenced by the values of standard deviation (0.04-0.03), classic coefficient of variation $(0.15-0.13)$ and range $(0.22-0.21)$. Also, the analysis of the measure of financial independence indicates a decrease in its diversity over the period considered, as indicated by standard deviation (0.09-0.08), classic coefficient of variation (0.37-0.35) and range $(0.49-0,47)$ (table 5).

TABLE 5

The map of spatial differentiation of the measure of synthetic financial situation and independence of municipalities of Świętokrzyskie Voivodship in 2009 and 2018

\begin{tabular}{|l|c|c|c|c|}
\hline \multirow{2}{*}{} & \multicolumn{2}{|c|}{$\begin{array}{c}\text { Measure of financial } \\
\text { situation }\end{array}$} & \multicolumn{2}{c|}{$\begin{array}{c}\text { Measure of financial } \\
\text { independence }\end{array}$} \\
\cline { 2 - 5 } & $\mathbf{2 0 0 9}$ & $\mathbf{2 0 1 8}$ & $\mathbf{2 0 0 9}$ & $\mathbf{2 0 1 8}$ \\
\hline average & 0.25 & 0.26 & 0.23 & 0.22 \\
\hline median & 0.24 & 0.25 & 0.21 & 0.21 \\
\hline standard deviation & 0.04 & 0.03 & 0.09 & 0.08 \\
\hline quarter (quartile) deviation & 0.25 & 0.26 & 0.22 & 0.21 \\
\hline classic coefficient of variation & 0.15 & 0.13 & 0.37 & 0.35 \\
\hline positional coefficient of variation & 1.02 & 1.02 & 1.05 & 0.98 \\
\hline min & 0.18 & 0.21 & 0.08 & 0.11 \\
\hline max & 0.40 & 0.42 & 0.57 & 0.58 \\
\hline range & 0.22 & 0.21 & 0.49 & 0.47 \\
\hline quartile 1 & 0.22 & 0.24 & 0.17 & 0.16 \\
\hline quartile 2 & 0.24 & 0.25 & 0.21 & 0.21 \\
\hline quartile 3 & 0.27 & 0.27 & 0.27 & 0.25 \\
\hline quartile range & 0.05 & 0.03 & 0.10 & 0.09 \\
\hline skewness & 1.09 & 1.89 & 1.24 & 2.09 \\
\hline measure of concentration-kurtosis & 1.62 & 5.92 & 2.11 & 7.29 \\
\hline
\end{tabular}

Source: author's own work based on data from RIO o / Kielce.

The correlation coefficient between the values of the synthetic measure in 2008 and 2018 was 0.835 and 0.839 , which may indicate the stability of spatial diversity in the examined aspect (table 6). The situation and level of financial independence is strongly correlated with own income, including taxes and local fees. The indicators inform about the possibility of generating income from own sources. This can be an indicator of sustainable development. The high value of correlation with the participation in CIT and PIT tax income may indicate the dependence of communes of Swiętokrzyskie voivodeship on income from the state budget. There are constant interactions between the level of socio-economic development, demographic potential and the labour market [Prus, Domagalska, 2010, pp. 174-178], entrepreneur- 
ship potential and the financial situation of the surveyed entities. Gunnar Myrdal, in the theory of cumulative causation referring to the analysis of the interdependence of social, economic and institutional phenomena, has proved that every element interacting with another element affects its behaviour, and at the same time is modified by the reaction of that element [Stanny, Strzelczyk, 2018].

TABLE 6

Correlation between measures of the financial situation, financial independence and socio-economic conditions in the municipalities of Świętokrzyskie Voivodship in 2009 and 2018

\begin{tabular}{|l|c|c|c|c|}
\hline \multirow{2}{*}{} & \multicolumn{2}{|c|}{$\begin{array}{c}\text { Measure of financial } \\
\text { situation }\end{array}$} & \multicolumn{2}{c|}{$\begin{array}{c}\text { Measure of financial } \\
\text { independence }\end{array}$} \\
\cline { 2 - 5 } & $\mathbf{2 0 0 9}$ & $\mathbf{2 0 1 8}$ & $\mathbf{2 0 0 9}$ & $\mathbf{2 0 1 8}$ \\
\hline Measure of financial independence & 0.8351 & 0.8393 & 1 & 1 \\
\hline Measure of financial situation & 1 & 1 & 0.8351 & 0.8393 \\
\hline Own income & 0.7627 & 0.7809 & 0.8656 & 0.8908 \\
\hline Income from taxes and local fees & 0.6645 & 0.7503 & 0.7850 & 0.8842 \\
\hline Participation in PIT tax income & 0.4157 & 0.5469 & 0.5490 & 0.5700 \\
\hline Participation in CIT tax income & 0.5050 & 0.6830 & 0.6006 & 0.7602 \\
\hline Capital expenses & 0.6548 & 0.5245 & 0.6132 & 0.4124 \\
\hline A measure of budget solvency & 0.5554 & 0.4988 & 0.1704 & 0.2571 \\
\hline A measure of state financial interference & 0.4138 & 0.6896 & 0.5593 & 0.8486 \\
\hline Service financing measure & 0.5177 & 0.6162 & 0.4153 & 0.3461 \\
\hline $\begin{array}{l}\text { Number of employed persons per 1000 } \\
\text { inhabitants }\end{array}$ & 0.4866 & 0.5942 & 0.6568 & 0.7111 \\
\hline Business entities per 1000 inhabitants & 0.4586 & 0.3424 & 0.5159 & 0.3684 \\
\hline $\begin{array}{l}\text { Natural persons conducting economic } \\
\text { activity per 1000 of population }\end{array}$ & 0.4531 & 0.2994 & 0.4792 & 0.3129 \\
\hline A measure of development potential & 0.5741 & 0.5428 & 0.6304 & 0.5900 \\
\hline A measure of entrepreneurship & 0.4562 & 0.3912 & 0.5448 & 0.4166 \\
\hline $\begin{array}{l}\text { A measure of demographic potential and } \\
\text { the labor market }\end{array}$ & 0.3676 & 0.4478 & 0.3419 & 0.3109 \\
\hline
\end{tabular}

the correlation table shows the areas with the highest correlation values; Linear correlation coefficients for observations from sample 1-102; critical value (at $5 \%$ bilateral critical area $)=$ 0.1946 for $\mathrm{n}=102$

Source: author's own work.

To assess the impact of communal endogenous potentials on the spatial diversity of the measure of the synthetic financial situation, a regression model describing the dependence of variables has been estimated taking the form: 


$$
\begin{gathered}
F(\text { financial situation })=\sum(\text { SF, DW, WI, MW, MIP, MFU, PR, PG, OS, MR, } \\
\text { MG, MD), }
\end{gathered}
$$

where: SF - Measure of financial independence, DW - Own income, WL - Capital expenses, MW - A measure of budget solvency, MIP - A measure of state financial interference, MFU - A measure of the level of financing services, PR - Number of employed persons per 1000 inhabitants, PG - Business entities per 1000 inhabitants, OS - Natural persons conducting economic activity per 1000 of population, MR - A measure of development potential, MG - A measure of entrepreneurship, MD - A measure of demographic potential and the labor market

TABLE 7

\section{Model regression measure of the synthetic situation and financial indepen- dence of municipalities in Świętokrzyskie voivodship in 2018}

\begin{tabular}{|c|c|c|c|c|}
\hline & Rate & Standard error & $t$-Student's & $p$-value \\
\hline constant & 0.175630 & 0.00572529 & 30.68 & $<0.0001$ \\
\hline $\begin{array}{c}\text { Measure of financial } \\
\text { independence }\end{array}$ & 0.385850 & 0.0249926 & 15.44 & $<0.0001$ \\
\hline
\end{tabular}

\begin{tabular}{|c|c|c|c|}
\hline $\begin{array}{c}\text { Arithmetic mean of the } \\
\text { dependent variable }\end{array}$ & 0.259118 & $\begin{array}{c}\text { Standard deviation of the } \\
\text { dependent variable }\end{array}$ & 0.034758 \\
\hline Sum of residual squares & 0.036063 & Residual Standard Error & 0.018990 \\
\hline $\begin{array}{c}\text { Coefficient of Determination } \\
\text { R-square }\end{array}$ & 0.704448 & Corrected R-square & 0.701493 \\
\hline F $(1,100)$ & 238.3500 & P-value for the F test & $3.21-28$ \\
\hline Logarithm of credibility & 260.5882 & Information criteria Akaike'a & -517.1763 \\
\hline $\begin{array}{c}\text { Bayesian information } \\
\text { criterion Schwarz }\end{array}$ & -511.9264 & Crit. Hannana-Quinna & -515.0505 \\
\hline
\end{tabular}

MNC estimation, observations 1-102 used; Dependent variable (Y): TOPSIS situation financial Source: author's own work.

The regression analysis of the measure of the synthetic situation and financial independence indicates that the presented regression model explains $R=0.704$ variable variations (at R2 = 0.701). Statistics values F $(1,100) 238.35$ and the corresponding probability level $\mathrm{p}$ mean that all parameters are statistically significant (table 7).

Regression analysis of the measure of the synthetic financial situation and the endogenous potential of municipalities that the presented regression model allows to explain $\mathrm{R}=0.416$ variations of variables (at $\mathrm{R} 2=0.392$; the interpretation value of this model turns out to be unsatisfactory). The model indicates the important role of occupational activity and entrepreneurship in the local economy. Statistics values $\mathrm{F}$ (4.97) 17.28 and the corresponding probability level $\mathrm{p}$ mean that all parameters are statistically significant (table 8). Further increasing the multidimensionality of the 
model would cause a slight increase in R2. The model could include statistically insignificant variables.

TABLE 8

A regression model measuring the synthetic situation and socioeconomic conditions of municipalities in Swiętokrzyskie voivodship in 2018

\begin{tabular}{|l|c|c|c|c|}
\hline \multicolumn{1}{|c|}{ constant } & Rate & Standard error & $t$-Student's & p-value \\
\hline $\begin{array}{l}\text { Number of employed persons } \\
\text { per 1000 inhabitants }\end{array}$ & 0.241594 & 0.0109735 & 22.02 & $<0.0001$ \\
\hline $\begin{array}{l}\text { Number of unemployed } \\
\text { per 1000 inhabitants }\end{array}$ & -0.000305379 & $4.96358 \mathrm{e}-05$ & 6.152 & $<0.0001$ \\
\hline $\begin{array}{l}\text { Business entities per 1000 in- } \\
\text { habitants }\end{array}$ & -0.00146062 & 0.000741243 & -1.971 & 0.0516 \\
\hline $\begin{array}{l}\text { Natural persons conducting } \\
\text { economic activity per 1000 } \\
\text { of population }\end{array}$ & 0.00166510 & 0.000804499 & 2.070 & 0.0411 \\
\hline
\end{tabular}

\begin{tabular}{|c|c|c|c|}
\hline $\begin{array}{c}\text { Arithmetic mean of the } \\
\text { dependent variable }\end{array}$ & 0.259118 & $\begin{array}{c}\text { Standard deviation of the } \\
\text { dependent variable }\end{array}$ & 0.034758 \\
\hline Sum of residual squares & 0.071237 & Residual Standard Error & 0.027100 \\
\hline $\begin{array}{c}\text { Coefficient of } \\
\text { Determination R-square }\end{array}$ & 0.416188 & Corrected R-square & 0.392114 \\
\hline $\mathrm{F}(4.97)$ & 17.28736 & P-value for the F test & $9.78 \mathrm{e}-11$ \\
\hline $\begin{array}{c}\text { Logarithm of credibility } \\
\text { Bayesian information } \\
\text { criterion Schwarz }\end{array}$ & -425.8707 & $\begin{array}{c}\text { Information criteria } \\
\text { Akaike'a }\end{array}$ & -441.7415 \\
\hline
\end{tabular}

MNC estimation, observations 1-102 used; Dependent variable (Y): TOPSIS situation financial Source: author's own work.

\section{Conclusions}

Commune self-governments are gaining more and more influence in terms of shaping their budgets, but the financial independence of municipalities is still the result of local entrepreneurship and local farming conditions. It is also the effect of the state's influence, which is expressed through subsidies and subventions.

Based on the conducted research, it was found that in 2018 the municipalities of Sitkówka-Nowiny (2), Połaniec (3), Kielce (1), Busko-Zdrój (3) were at the same time characterized by good standing and financial independence. The measure of financial standing ranged from 0.21 to 0.42 , while in 2009 from 0.18 to 0.40 . Municipalities characterized by an industrial, or tourist and spa function were characterized by a better level of financial situation than those with the agricultural function. 
The spatial differentiation between own income and investment expenses is a challenge for local authorities. In addition, municipalities differ in social, economic, natural conditions and infrastructure potential. Information on the state of finances is the basis for a comprehensive assessment of the activities of the local government, the rational management of public money resources and the expenses will indicate the development possibilities of these units.

A proper financial situation and independence are a condition of sustainable social and economic development of the region. Their assessment is important from the point of view of the effectiveness of municipalities. The results of the study give municipalities a comparison of their own situation with the situation of other municipalities. The presented method of synthetic measure allows the identification of areas of higher or lower level in the studied area. It can be a tool for local authorities used to assess the accuracy of decisions taken in the past and the effectiveness of municipal management instruments used in the past or to set potential directions for optimizing the structure of local finances and of the development process.

\section{References}

Behzadian M., Khanmohammadi Otaghsara S., Yazdani M., Ignatius J., 2012, A state-of the-art survey of TOPSIS applications, "Expert Systems with Applications", vol. 39(17), pp. 13051-13069, DOI: 10.1016/j.eswa.2012.05.056.

Cabaleiro-Casal R., Buch-Gómez E. J., Vaamonde Liste A, 2013, Developing a Method to Assessing the Municipal Financial Health, "American Review of Public Administration”, vol. 43(6), pp. 729-751, DOI: 10.1177/0275074012451523.

Churski P., Borowczak A., Dolata M., Dominik J., Hauke J., Perdał R., KoneckaSzydłowska B., 2013, Cazynniki rožpoju obszarón wzrostu i obszarów stagnacji gospodarczej w Polsce, Raport IV, Uniwersytet im. Adama Mickiewicza, Poznań.

Dennis L., 2004, Determinants of Financial Condition: A Study of US Cities. Orlando, University of Central Florida, Orlando.

Douglas J.W., Gaddie R.K., 2002, State rainy day funds and fiscal crises: Rainy day funds and the 1990-1991 recession revisited, "Public Budgeting \& Finance", vol. 22, pp. 19-30, DOI: $10.1111 / 1540-5850.00063$.

Dziekański P., 2016, Spatial Differentiation of the Financial Condition of the Świetokrayskie Voivodship Counties, „Barometr Regionalny. Analizy i Prognozy”, nr 3(45), s. 89-101.

Filipiak B., 2011, Finanse samorzadowe. Nowe myz̧wania bieżace i perspektywiczne, Wydawnictwo Difin, Warszawa.

Galiński P., 2011, Samodzielność finansowa jednostek samorz̨adu terytorialnego - pojecie, determinanty, ocena, https://www.prawo.pl/samorzad/samodzielnosc-finansowa-jednostek-samorzadu-terytorialnego-pojecie-determinanty-ocena,79323.html [date of entry: 15.04.2020].

Głowicka-Wołoszyn R., Wysocki F., 2014 Uwarunkowania społeczno-ekonomiczne samodzielności finansowej gmin województwa wielkopolskiego, „Prace Naukowe Uniwersytetu Ekonomicznego we Wrocławiu”, nr 346, s. 34-44, DOI: 10.15611/pn.2014.346.03. 
Hwang C.L., Yoon K., 1981, Multiple attribute decision making. Methods and applications, Springer, Berlin [za:] Bieniasz A., Gołaś Z., Luczak A., 2013, Zróżnicowanie kondycji finansowej gospodarstw rolnych myspecjalizowanych w chowie owiec i kóz w krajach Unii Europejskiej, „Roczniki Ekonomii Rolnictwa i Rozwoju Obszarów Wiejskich”, t. 100, z. 1, s. 169-171.

Kolenda M., 2003, Zamiana cechy na stymulante, „Prace Naukowe Akademii Ekonomicznej we Wrocławiu. Ekonometria”, t. 11(981), s. 110-127.

Kosek-Wojnar M., 2006, Samodrielność jednostek samorzadu terytorialnego w sferze nydatków, „Zeszyty Naukowe Wyższej Szkoły Ekonomicznej w Bochni”, nr 4, s. 75-88.

Kosek-Wojnar M., Surówka K., 2002, Finanse samorzadu terytorialnego, AE Kraków, Kraków.

Kozera A., Głowicka-Wołoszyn R., Wysocki F., 2016, Samodzielność finansowa gmin wiejskich w woj. Wielkopolskim, „Wiadomości Statystyczne”, nr 2, s. 73-87.

Malina A., 2004, Wielowymiarowa analiza przestrzennego zróżnicowania struktury gospodarki Polski wedtug województw, Wyd. Akademii Ekonomicznej w Krakowie, Kraków.

Młodak A., 2006, Analiza taksonomiczna w statystyce regionalnej, Centrum Doradztwa i Informacji Difin, Warszawa.

Ossowska L., Ziemińska A., 2010, Kondygja finansowa gmin wiejskich $i$ miejsko-wiejskich wojewódżtwa pomorskiego, ,Journal of Agribusiness and Rural Development", vol. 4(18), pp. 73-85.

Pietrzak M.B., 2016, The problem of the inclusion of spatial dependence within the TOPSIS Method, "Montenegrin Journal of Economics", vol. 12(3), pp. 69-86, DOI: 10.14254/1800-5845.2016/12-3/5.

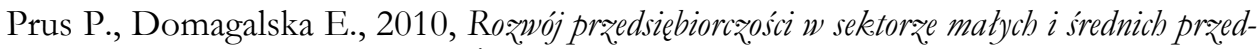
siebiorstw na prsylktadzie gminy Żnin, „Roczniki Naukowe SERiA”, t. 12(5), s. 174-178.

Prus P., Wawrzyniak B.M., 2011, Zarzqdzanie projektami i funkcije gmin w zakeresie programón rozwoju obszarów wiejskich, „Studia i Materiały Polskiego Stowarzyszenia Zarządzania Wiedzą", t. 44, s. 77-92.

Rechul H., 2013, Samodzielność finansowa jednostek samorzadu terytorialnego w Polsce, „Prace Naukowe Uniwersytetu Ekonomicznego we Wrocławiu”, nr 306, s. 325-337.

Satoła L., Standar A., Kozera A., 2019, Financial autonomy of local government units: Evidence from Polish rural municipalities, „Lex Localis”, vol. 17(2), pp. 321-342, DOI: 10.4335/17.2.321-342(2019).

Sobczyk A., 2010, Rozwój lokalny - mybrane problemy finansowania, „Zeszyty Naukowe SGGW - Ekonomika i Organizacja Gospodarki Żywnościowej”, nr 81, s. 125-136.

Standar A., 2017, Ocena kondycji finansowej gmin orazjej uybranych uwarunkowan na praykładzie województwa wielkopolskiego pray wykorzystaniu metody TOPSIS, „Wieś i Rolnictwo", nr 2(175), s. 69-92, DOI: 10.7366/wir022017/04.

Stanny M., Strzelczyk W., 2017, Pomiar kondycji finansowej jednostek samorzadu lokalnego - kwerenda miedsynnarodowa, „Nierówności Społeczne a Wzrost Gospodarczy”, nr 49(1), s. 372-383, DOI: 10.15584/nsawg.2017.1.28.

Stanny M., Strzelczyk W., 2018, Kondycja finansowa samorzadów lokalnych a rozwój spoteczno-gospodarczy obszarón wiejskich. Ujecie przestrzenne, Instytut Rozwoju Wsi i Rolnictwa PAN, Wydawnictwo Naukowe Scholar Spółka z o.o., Warszawa. 
Surówka K., 2013, Samodzielność finansowa samorz̨adu terytorialnego w Polsce, Polskie Wydawnictwo Ekonomiczne Warszawa.

Wang X., Dennis L., Sen Y., 2007, Measuring financial condition: a study of U.S. states, "Public Budgeting \& Finance", vol. 27(2), pp. 1-22, DOI: 10.1111/j.1540-5850. 2007.00872.x.

Wójcik-Leń J., Leń P., Mika M., Kryszk H., Kotlarz P., 2019, Studies regarding correct selection of statistical methods for the needs of increasing the efficiency of identification of land for consolidation - A case study in Poland, „Land Use Policy”, vol. 87, DOI: 10.1016/ j.landusepol.2019.104064.

Wyszkowska D., 2018, Samodzielność finansowa jako determinanta potencjału inwestycyjnego jednostek samorzadu terytorialnego: studium empiryczne gmin w Polsce, Wydawnictwo Uniwersytetu w Białymstoku, Białystok.

Wyszkowska D., Wyszkowski A., 2015, Samodzielność dochodowa samorzadu terytorialnego w Polsce, „Studia i Materiały Wydziału Zarządzania i Administracji Wyższej Szkoły Pedagogicznej im. Jana Kochanowskiego w Kielcach”, nr 2 (19), s. 131-142.

Zalewski W., 2012, Zastosowanie metody TOPSIS do oceny kondycii finansowej spótek dystrybucyjnych energii elektrycznej, „Ekonomia i Zarządzanie”, nr 4, s. 137-145.

Zeliaś A., Malina A., 1997, O budowie taksonomicznej miary jakości syycia. Syntetyczna miara rozwoju jest narzedziem statystycznej analizy porównawczej [w:] Taksonomia $\mathrm{nr} 4$. Klasyfikacja $i$ analiza danych. Teoria $i$ zastosowania, Jajuga K., Walesiak M. (red.), Wydawnictwo Akademii Ekonomicznej we Wrocławiu, Wrocław. 